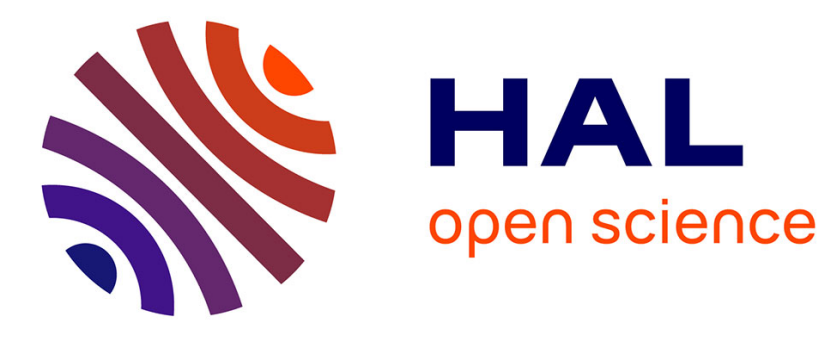

\title{
A Coffin for Malthusianism: Josué De Castro's Subaltern Geopolitics
}

Federico Ferretti

\section{To cite this version:}

Federico Ferretti. A Coffin for Malthusianism: Josué De Castro's Subaltern Geopolitics. Geopolitics, 2019, pp.1-26. 10.1080/14650045.2019.1583213 . hal-02062990

\section{HAL Id: hal-02062990 \\ https://hal.science/hal-02062990}

Submitted on 10 Mar 2019

HAL is a multi-disciplinary open access archive for the deposit and dissemination of scientific research documents, whether they are published or not. The documents may come from teaching and research institutions in France or abroad, or from public or private research centers.
L'archive ouverte pluridisciplinaire HAL, est destinée au dépôt et à la diffusion de documents scientifiques de niveau recherche, publiés ou non, émanant des établissements d'enseignement et de recherche français ou étrangers, des laboratoires publics ou privés. 
A coffin for Malthusianism: Josué de Castro's subaltern geopolitics

Federico Ferretti

federico.ferretti@ucd.ie

This paper addresses the idea of geopolitics of hunger as proposed by a Brazilian geographer, Josué de Castro, whose originality and international impact in the fields of critical geography and development studies still merit fuller acknowledgment both within and beyond the discipline of geography. Drawing upon archival research on de Castro's correspondences and scholarly networks and on the editorial history of his key book Geopolitics of Hunger, first I argue that de Castro was a forerunner of the definition of geopolitics in a critical sense, and that this nonconformist attitude has been one of the primary reasons for his persistent scholarly neglect. Second, I argue that de Castro's anti-colonial geopolitics, based on subaltern agency, furnishes powerful arguments to present-day critics of 'food security', who challenge the revival of Malthusian concepts, Euro-centric views and neo-colonial recipes in development debates, a clear geopolitical matter for contemporary scholarly and political conversations. Finally, de Castro's international networking, and his biography as a political dissident and exile, provide some useful practical examples of performing geopolitical discourses outside institutional and statist frameworks.

Keywords: Subaltern Geopolitics; Hunger Studies; Northeast of Brazil; Food Security; AntiMalthusianism

This paper addresses the idea of geopolitics of hunger as proposed by a geographer from Pernambuco, in north-eastern Brazil, Josué de Castro (1908-1973), whose originality and international impact in the fields of critical geography and development studies still merit fuller acknowledgment. Building upon recent literature on another important Brazilian geographer from the Northeast (from Bahia), Milton Santos (Melgaço 2017, Melgaço and Prouse 2017; Ferretti and Viotto 2018), I focus on the idea of geopolitics as addressed in the scholarly production of de Castro who, like Santos, was exiled during the military dictatorship which ruled Brazil from 1964 to 1985 (Ferretti 2018). Known internationally for his works on the

F.Ferretti, 2019 “A coffin for Malthusianism: Josué de Castro's subaltern geopolitics”, Geopolitics early view: https://www.tandfonline.com/doi/full/10.1080/14650045.2019.1583213 
geographies and geopolitics of hunger during his lifetime, de Castro remains a neglected figure in international scholarship. Yet, he provided important insights in criticising Euro-centric models of development and 'food security' through his advocacy for the specificities of his region, the Northeast of Brazil, and for the specific needs of what was then called the 'Third World'. Though ignored for a long time by geographers, de Castro is still a major inspiration for some intellectuals who explicitly rely on his political and intellectual legacy, such as Jean Ziegler, a former FAO officer and a de Castro's acquaintance (Ziegler 2013), and agriculture scholar Jahi Chappell (2018). De Castro's works are now the object of rediscovery for Brazilian historians, geographers and medical scholars (Fontana 2014; Santos Silva 2016; Teles de Carvalho 2009) while, in English-speaking geographical scholarship, his name is still almost unknown, with some notable exceptions like Archie Davies's $\mathrm{PhD}$ thesis at King's College ${ }^{1}$ nd a recent paper by Eric Carter on population control in Latin America, which includes a section analysing de Castro's anti-Malthusianism (Carter 2018).

At the beginning of the 1950s, one of the most original among Josué de Castro's main intellectual contributions was his key book Geopolitics of Hunger, pioneering the use of the word 'geopolitics' in critical terms and offering potential insights for contemporary research strands in this field. De Castro's ideas resonate with definitions of alter-geopolitics by authors like Sara Koopman who argues (after the Zapatistas) that, when challenging the violence of power, 'there is one no and many yeses' (Koopman 2011, 277), meaning that social and progressive movements are a plural and multifaceted field. De Castro's 'yeses' referred to the variegated social movements, institutional and non-institutional, which committed to fighting poverty and social inequalities at that time and which would be collated today under the umbrella of 'progressive geopolitics' (Kearns 2008). His big 'no' was resolutely directed to top-down Malthusian recipes for Third World 'development' widely exported by Northern neocolonial powers during the Cold War and still discussed in current geographical and geopolitical debates (Nally 2016).

\footnotetext{
${ }^{1}$ Archie Davies, Josué de Castro's Geografia Combatente and the political ecology of hunger, $\mathrm{PhD}$ thesis. Supervised by Alex Loftus and Jeff Garmany, Department of Geography, King's College London (to be discussed in March 2019).
}

F.Ferretti, 2019 “A coffin for Malthusianism: Josué de Castro's subaltern geopolitics”, Geopolitics early view: https://www.tandfonline.com/doi/full/10.1080/14650045.2019.1583213 
As scholars in the field well know, in the aftermath of the Second World War geopolitics was a wretched term, while critical and 'leftist' uses of this definition were internationally established only from the 1990s (Flint and Mamadouh 2015). In their seminal work on the geopolitical traditions, Klaus Dodds and David Atkinson noticed that it is possible to find the word 'geopolitics' in English-speaking literature also in some cases from the 1950s, although this happened without major theoretical questionings of its meaning (Dodds and Atkinson 2000). However, de Castro's geopolitics of hunger is not quoted in the classical works on critical geopolitics, such as Dodds and Atkinson's, the seminal book by Gearoid Ó Tuathail (1996) or the more recent Ashgate Research Companion to Critical Geopolitics (Dodds, Kuus and Sharp 2013). A cursory study of the online collections of the major international journals in this field shows that, at least until April 2018, de Castro was never mentioned in Geopolitics and, only very recently, was he quoted in a couple of Political Geography papers. Filling this lacuna is essential to better understanding the multilingual and transnational construction of critical geopolitical traditions and to reflect on how this notion can nourish current debates on critical geopolitics of food crises, as I explain below.

As clearly exposed in the pioneering works by Ó Tuathail, critical geopolitics was first intended as an alternative to more traditional forms of political geographies related to statecraft. Critical geopolitics was defined as a study requiring 'consideration of the much broader question of the production of geographical knowledge [especially characterised by] the study of geopolitical reasoning within the context of the study of hegemony in a nonstatist, Gramscian-inspired sense' (Ó Tuathail 1996, 47). According to Simon Dalby, critical geopoliticians 'must not limit [their] attention to a study of the geography of politics within pregiven, taken-for-granted, commonsense spaces, but investigate the politics of the geographical specification of politics. That is to practice critical geopolitics' (Dalby 1991, 274). Later elaborations understood the definition of 'anti-geopolitics' used by scholars like Paul Routledge as a field of study which 'represents an assertion of permanent independence from the state, whoever is in power' (Routledge 1998, 245). To expose similar concerns, also definitions such as 'radical geopolitics' or 'subaltern geopolitics' are used in current scholarship. According to Julien Mercille, the first draws on tendencies towards 'deeper engagements with politics and activism' (Mercille 2013, 129). The second, for Joanne Sharp, addresses 'subaltern imaginaries that offer

F.Ferretti, 2019 “A coffin for Malthusianism: Josué de Castro's subaltern geopolitics”, Geopolitics early view: https://www.tandfonline.com/doi/full/10.1080/14650045.2019.1583213 
creative alternatives to the dominant (critical) geopolitical scripts. The concept of subaltern makes a direct reference to postcolonial notions of power relations, suggesting a position that is not completely other, resistant or alternative to dominant geopolitics' (Sharp 2011, 271).

Today, these critical approaches to geopolitics are buttressed by a burgeoning literature. De Castro's life and works anticipated some of the key features of these contributions, providing possible insights into the related debates and an historical example of resisting what Sharp has defined as the 'moral geopolitical model of good and evil' (Sharp 2000, 12) put in place by the United States during the Cold War. De Castro spoke from the 'Global South' providing an original scholarly standpoint from outside the dominant field of the Anglophone literature and eventually from a country, Brazil, whose radical scholarly traditions have become an important focus for international literature. For instance, a key contribution by Rachel Pain on the 'emotional geographies' draws upon Paulo Freire's notion of conscientização, that is 'the development of critical consciousness from within' (Pain 2009, 480) to address a complex agenda of emotional geopolitics going beyond unidirectional accounts of violence and fear and understanding agendas of 'resistance, agency and action' (Pain 2009, 475). Brazilian educator Paulo Freire (1921-1997) was born in Recife, where he was acquainted with local geographers' networks and was likewise an exile of the military dictatorship (Ferretti 2019). Another feature of de Castro's work pioneering later contributions was the emphasis that he placed on corporeal realities of hunger and the associated feelings and sufferings. This correspond with claims from feminist geopolitical scholarship against the disembodied readings characterising big geopolitical narratives (Dowler and Sharp 2011) and against geopolitics intended as a game for 'big men moving big guns across a big playing field' (Koopman 2011, 274). On this last point, de Castro's participation in international conferencing for disarmament during the Cold War can also be a matter for discussion in the current fields of geographies of peace and 'pacific geopolitics' (Mc Connell, Megoran and Williams 2014; Megoran 2011).

De Castro acted as an official representative for the Brazilian government in international organisations such as the FAO and the UNESCO until his banishment in 1964, working in the circles of experts which have been defined as parts of 'bureaucratic knowledge production' (Kuus 2014, 196). However, in the last decade of his life, the Brazilian geographer had to work

F.Ferretti, 2019 “A coffin for Malthusianism: Josué de Castro's subaltern geopolitics”, Geopolitics early view: https://www.tandfonline.com/doi/full/10.1080/14650045.2019.1583213 
from a marginalized position, operating as an activist and something like an informal diplomat' during his exile. Therefore, de Castro's work can be of special interest for the notion of geopolitical 'liminality' recently discussed by geographical scholarship, which includes 'the blurring of boundaries between diplomacy and activism, and the notion of geopolitical shapeshifters' (McConnell 2016, 141), assuming that 'self-identified political activists rarely gain entry into the forums of international diplomacy' (McConnell 2016, 147). The foundation of the CID (Centre International du Développement) by de Castro in 1964 can be an example in the importance of the 'margins' of geopolitics advocated by authors working on liminality.

Among these heterogeneous but connected strands of research, the definition of subaltern geopolitics chimes especially well with my arguments, as de Castro's analyses were largely based on Brazilian peasantry and on what is considered in Gramscian terms as subaltern spaces (Clayton 2011). This includes the possibility, mentioned by James Sidaway, Virginie Mamadouh and Marcus Power, to approach geopolitics 'from the vantage point of postcolonial critique. Such an approach foregrounds the imperial framing of geopolitics' (Sidaway, Mamadouh and Power 2013, 168). These authors' idea that one should 'not only pay attention to the geopolitics of hegemonic states and contenders for power, but also of states and actors at the margins of world politics' (Sidaway, Mamadouh and Power 2013, 169) is substantiated by cases like Latin American geopolitics and their varied traditions. In Latin America, states in mutual competition remained 'confronted with the same Iberian formal imperial heritage, the same British informal imperial past and the same US informal imperial present' (Sidaway, Mamadouh and Power 2013, 170). Elaborated in the early years of the Cold War, de Castro's geopolitics of hunger indirectly took advantage of 'the long years of military rule [which] gave the Brazilian generals a chance to elaborate and impose a geopolitical vision on the country' (Sidaway, Mamadouh and Power 2013, 171), but which also stimulated the international networking of exiles and dissidents (Ferretti 2018).

My argument is twofold. First, I argue that de Castro foreshadowed key features of the literature discussed above by placing his scholarly work in a definitively anti-colonialist, anti-racist and activist global perspective. Second, de Castro's geopolitics can contribute to challenging today 'hungercrats' (Nally 2016) by providing an example of engaged scholarship that criticised

F.Ferretti, 2019 “A coffin for Malthusianism: Josué de Castro's subaltern geopolitics”, Geopolitics 
universal recipes for 'development' imposed by the North and analysed the phenomenon of hunger in the context of environmental, social and cultural relations characterising each region. Albeit committed to fighting hunger worldwide, de Castro first addressed the cases of Brazil and of its Northeast, stressing the importance of studying the complexity of local cultures, societies, histories and environmental frameworks to resolve problems. For de Castro, all solutions should be sensitive to, and respectful of, local conditions and ecological equilibria, rather than the imposition of top-down solutions by governments or business corporations.

To progress my argument, I examine de Castro's life, works and networks through substantial archival materials. From a methodological standpoint, I draw upon Mike Heffernan's concept that, 'to avoid a teleological reading of the past and subvert the idea that geopolitics has flowed in a single intellectual trajectory from the ideologically and morally suspect geopolitics of the late 19th and early 20th century through the radical alternatives of the 1960s and 1970s to a post-structural, "critical geopolitics" in the present' (Heffernan 2000, 347). In this sense, it is important to put notions in their places and in their (cultural, social, historical) contexts including their authors' biographies. To this end, I researched de Castro's exceptionally rich and little studied archives surviving in the Coordenação-Geral de Estudos da História Brasileira (CEHIBRA) at the Fundação Joaquim Nabuco (FUNDAJ) in Recife, which only recently opened this collection to researchers (Ferretti, 2018). From these materials I reconstructed his international networks and analysed his key texts on geopolitics of hunger in their historical, geographical and editorial contexts.

In the next part of this paper, I address de Castro's early works in Recife and the beginnings of his international scholarly networks and connections with French geographers, which explain the choice of Paris for his subsequent exile. Then, I discuss de Castro's key book Geopolitica da Fome in comparison with the history of this definition in French and English-speaking scholarship, to highlight his early role as a forerunner of critical geopolitics. Subsequently, drawing upon critical geographical and geopolitical scholarship on development and 'food security', I explore the anti-colonial and anti-Malthusian contents of de Castro's works, before addressing de Castro's attempts to perform geopolitics from below in Brazil and later in France.

F.Ferretti, 2019 “A coffin for Malthusianism: Josué de Castro's subaltern geopolitics”, Geopolitics early view: https://www.tandfonline.com/doi/full/10.1080/14650045.2019.1583213 


\section{Early life in Recife and French connections}

Josué Apolônio de Castro was born in Recife, the capital of Pernambuco, to a middle-class family from the Sertão (hinterland or backland). Like de Castro, other critical and radical geographers such as Milton Santos and Manuel Correia de Andrade came from the Northeast, traditionally the poorest region of the country and one of the centres of non white Brazilian culture (Hecht 2013). Though relatively well-heeled in this context, the young de Castro developed an early sensitivity to problems of poverty that plagued his region by frequenting the mocambos (informal Afro-Brazilian settlements) around Recife. In North-eastern Brazil, poverty was often associated with the traditional racial stigma which affected its inhabitants, for a large part descending from African slaves or indigenous through processes of miscegenation where non-European components were traditionally major than in other parts of Brazil. As Ziegler observed, de Castro was especially sensitive to racial issues, 'being himself a caboclo, of mixed indigenous Brazilian and European ancestry' (Ziegler 2013, 73). First trained as a medical doctor, Josué soon became interested in interdisciplinary approaches to addressing poverty and hunger based on principles of anthropology, sociology and human geography (Andrade 2003 and 2007; Teles de Carvalho 2009). His first works were inspired by the regional and geo-historical approaches of French géographie humaine (Castro 1937). The special link between de Castro and his region is also witnessed by the numerous references he made to Euclides da Cunha (1866-1909) one of the authors who have currently been rediscovered for their interest in the revolts and contribution of non-white Brazilian people, mainly from the Northeast, to Brazilian history and national formation (Hecht 2013). De Castro's Geografia da Fome was especially devoted 'to the memory of Euclides da Cunha ... historian of hunger' (Castro 1946, exergue).

At the same time, de Castro's experience as a geography teacher (in Recife from 1932 to $1934^{2}$ and from 1937 to 1955 in Rio) was characterised from the beginning by his international networking, especially through correspondence with French scholars, and by a strong interest in anthropology with a special focus on Afro-Brazilian communities. In the 1930s, de Castro

\footnotetext{
${ }^{2}$ Recife, Fundação Joaquim Nabuco, Coordenação-Geral de Estudos da História Brasileira Rodrigo Melo Franco de Andrade, Acervo Josué de Castro (hereafter CEHIBRA), Folder 393, Biografia. All quotes from sources in Portuguese, Spanish or French have been translated by the author.
}

F.Ferretti, 2019 “A coffin for Malthusianism: Josué de Castro's subaltern geopolitics”, Geopolitics early view: https://www.tandfonline.com/doi/full/10.1080/14650045.2019.1583213 
corresponded with poet Mario de Andrade (1893-1945) stating his interest in French social anthropology ${ }^{3}$ and with Luís da Câmara Cascudo (1898-1986) from Natal (Rio Grande do Norte), who frequently wrote back to him evoking projects of 'a geography of Brazilian myths' focussing on 'indigenous' and 'African' geographies. ${ }^{4}$ Cascudo was likewise interested in 'Brazilian cuisine' ${ }^{5}$ and, like de Castro, was in touch with Arthur Ramos (1903-1949), ${ }^{6}$ a scholar of Afro-Brazilian communities from Alagoas, who recorded the Bumba-meu-boi. ${ }^{7}$ This was a popular song reproduced in de Castro's paper Fisiologia dos Tabus (1938), in which the geographer, in studying the permanence of alimental prohibitions of totemic origin in AfroBrazilian communities, linked these permanencies with the reality of hunger. According to the song, a cowboy 'from the entire body of the ox does not find the smallest morsel of meat (anguished rhythm)' (Castro 1965, 31). These works and networks show how, in de Castro's circuits, matters of alimentation and material culture were linked to cultural studies of subaltern groups and especially to north-eastern Blacks and caboclos.

This interest was shared by anti-racist French anthropologist Roger Bastide (1898-1974). Bastide, still a little-known figure even in France, was a participant in French projects of university cooperation in Brazil and taught in São Paulo from 1938 to 1957, producing an important output on Afro-Brazilian religions. ${ }^{8}$ When Bastide arrived in Brazil, de Castro was one of his first friends and guides. In April 1938, upon sending his works to de Castro, Bastide endorsed the Brazilian geographer's writings on alimentary taboos and advanced a special request for his forthcoming visit to Rio: 'Would it be possible to visit a terreiro [place for celebration in Afro-Brazilian religions] and perhaps to attend a macumba?... If so, could you be my guide, as you are so well versed in African topics?' ${ }^{9}$ Bastide's letters sent over the following months show that the two scholars effectively arranged such a visit. Bastide also corresponded on the same topics with Ramos, to whom he was accordingly introduced by de

\footnotetext{
3 São Paulo, Instituto de Estudos Brasileiros (hereafter IEB) MA-C-CPL1908, 7 April 1937, de Castro to de Moraes Andrade.

${ }^{4}$ CEHIBRA, 574, Camara Cascudo to de Castro, 22 January 1938.

${ }^{5}$ CEHIBRA, 582, Camara Cascudo to de Castro, 19 October 1937.

${ }^{6}$ CEHIBRA, 582, Camara Cascudo to de Castro, 2 September 1937.

${ }^{7}$ CEHIBRA, 582, Camara Cascudo to de Castro, 11 September 1937.

${ }^{8}$ Bastide's archives are held at the São Paulo IEB and at the French Institut Mémoire de l'Edition Contemporaine and require further study.

${ }^{9}$ CEHIBRA, 584, Bastide to de Castro, 10 April 1938.
}

F.Ferretti, 2019 “A coffin for Malthusianism: Josué de Castro's subaltern geopolitics”, Geopolitics early view: https://www.tandfonline.com/doi/full/10.1080/14650045.2019.1583213 
Castro. ${ }^{10}$ In writing to Ramos, Bastide mentioned his visit to Rio enthusiastically, requesting that Ramos have him visit 'the first Afro-Brazilian Museum that you have seen'. ${ }^{11}$ In the following years, Bastide corresponded extensively with Ramos, also suggesting him a reading on the Afro-American communities of Central and North America: 'Elisée Reclus [whom] I like very much for his capacity to evoke the people's lives' ${ }^{12}$ This confirms the importance of radical geographical traditions to the formation of geopolitics of hunger. De Castro likewise used to quote the French anarchist geographer (Castro 1965).

De Castro was acquainted with the French geographers who contributed to the first Brazilian public universities, the Universidade de São Paulo (USP) founded in 1934 and the Rio Federal University founded in 1935 (Borzacchiello 2016). In evoking de Castro's potential move to the USP, Bastide endorsed his 'conference on human alimentation in the Tropics'"13 and engaged in discussions on social and cultural aspects of Afro-Brazilian families requesting that the Brazilian geographer act as an informer for this project. The two correspondents also shared an interest in the works of Gilberto Freyre, whose book Mocambos do Nordeste (1937) was among de Castro's readings. ${ }^{14}$ Bastide's colleague in São Paulo and the 'Big Man' of French-Brazilian academic cooperation in geography, Pierre Monbeig (1907-1987) was equally interested in de Castro's conferences and invited him to give speeches at the 'Association of Brazilian Geographers', ${ }^{15}$ again on the Mocambos. ${ }^{16}$ In Rio, de Castro was also given the opportunity to work with Pierre Deffontaines (1894-1978), another participant in French university missions held in Brazil (Sampaio Machado 2009) and a social and engaged geographer who was accordingly the most interested French scholar in de Castro's focuses.

In a 1937 letter Deffontaines appreciated de Castro's book A alimentação brasileira à luz da geografia humana (1937), arguing that: 'To my opinion, food problems are the most important

\footnotetext{
${ }^{10}$ CEHIBRA, 584, Bastide to de Castro, 20 September 1938.

${ }^{11}$ Rio de Janeiro, Fundação Biblioteca Nacional, Correspondência de Arthur Ramos 1903-1949 (hereafter BNRJ), Bastide to Ramos, 20 September 1938.

12 BNRJ, Bastide to Ramos, 6 April 1946.

13 CEHIBRA 574, Bastide to de Castro, 23 June 1939.

${ }^{14}$ CEHIBRA, 349, Os mocambos do Nordeste, 1939.

${ }^{15}$ CEHIBRA, 574, Monbeig to de Castro, 1 June 1939.

16 CEHIBRA, 574, de Castro to Monbeig, n.d.
}

F.Ferretti, 2019 “A coffin for Malthusianism: Josué de Castro's subaltern geopolitics”, Geopolitics early view: https://www.tandfonline.com/doi/full/10.1080/14650045.2019.1583213 
of all problems of human geography. Unfortunately, studies on these topics are still rare'. ${ }^{17}$ Deffontaines distanced himself from the French mainstream geography of the first half of the $20^{\text {th }}$ century, which was mostly hostile to social and political engagement, confirming his originality as a socially committed geographer inspired by the milieus of social Catholicism (Ferretti 2014). This can be extended to de Castro, who was likewise a Catholic and collaborated with some French progressive and socially-engaged priests such as Abbé Pierre and the Dominican supporter of social planning Louis-Joseph Lebret (Ramos de Angelo 2010).

In writing to de Castro, Deffontaines expressed his willingness to 'visit your Northeast, one of the most extraordinary regions for studying human geography'. ${ }^{18}$ This illustrates the importance of de Castro's early networking with French scholars, which can explain why he chose to travel to France for his exile in 1964, to perform there his 'geopolitics from below'. From both a political and a scholarly point of view, de Castro's passion for Afro-Brazilian and caboclos' communities, his rootedness in the subaltern histories and traditions of Brazilian Northeast and his early interest in French social geography, can explain radical characteristics of his geopolitics of hunger, especially its anti-racism and anti-Malthusianism. In the next section, I expose these features of de Castro's thinking, first regarding Brazil and then in their global dimension.

\section{Pioneering critical geopolitics}

One of the most prestigious geographers of the 'French School', Max Sorre (1880-1962), wrote to de Castro in 1949 to acknowledge reception of the French translation of Geografia da Fome and to express his agreement with de Castro's claims for the social relevance of geographies of food, showing to be already aware of earlier de Castro's writings published in Portuguese. ${ }^{19}$ This is an indicator of the scholarly attention existing then towards de Castro's works, which were read by Northern scholars before their translation into French or English. As exposed by recent scholarship (Ferretti and Viotto 2018), works such as those by de Castro, together with those of Santos, clearly had an impact on the discovery of the problems of hunger and

\footnotetext{
${ }^{17}$ CEHIBRA 582 Deffontaines to de Castro, 15 August 1937.

${ }^{18}$ CEHIBRA, 582, Deffontaines to de Castro, 30 September 1937.

${ }^{19}$ CEHIBRA, 581, Sorre to de Castro, 14 December 1949.
}

F.Ferretti, 2019 “A coffin for Malthusianism: Josué de Castro's subaltern geopolitics”, Geopolitics early view: https://www.tandfonline.com/doi/full/10.1080/14650045.2019.1583213 
'underdevelopment' by French geographers. De Castro was quoted in early papers by Yves Lacoste (1962) and, according to Manuel Correia de Andrade, he collaborated with Monbeig for the foundation of the Institute of Advanced Studies on Latin America (Andrade 1997, 7), which shows the continuity of his French networks between the 1930s and the 1960s.

Whilst Geografia da Fome focused on hunger in Brazil, the 1951 book Geopolitica da Fome, translated into English and French in 1952 (and in several other languages later), had a wide impact, especially around milieus of the United Nations. The first French edition, Géopolitique de la Faim, had a foreword from Sorre, who first highlighted de Castro's anti-Malthusianism, arguing that 'old Malthus's formulas are no longer acceptable' (Sorre 1952, 10) and defining de Castro's book as 'a plea against imperialism and colonialism' (Sorre 1952, 11). In the same year, Pearl Buck's foreword to the Brown North-American edition (reproduced in the French edition) stressed the same points, adding a revealing statement: against Malthus, Buck considered de Castro's work as a demonstration that 'survival depends not on struggle, but on mutual aid' (Castro 1952a, 14). This was an implicit but very clear reference to the ideas of Peter Kropotkin, an author who was not directly quoted by de Castro, but who belonged to the anarchist tradition of which de Castro was aware by way of Elisée Reclus, one of his first authors of reference since his youth (Ferretti, 2018). Moreover, de Castro's arguments countered the dogma of scarcity, witnessing at the same time the importance of Malthusian arguments in the years which followed the 'invention of underdevelopment' by USA President Harry Truman in 1949 (Power 2003; Sachs 1992). Therefore, the impact of this book in development debates of the 1950s was likely to be perceived as radical.

Whilst Géopolitique de la faim was published in 1952, the starting point of French critical geopolitics is commonly identified as being 1976, when Yves Lacoste commenced editing the journal Hérodote and at the same time published his famous book La géographie ça sert d'abord à faire la guerre (Lacoste, 1976). The year before, in the Annales de Géographie, André Louis-Sanguin had still expressed notions of geopolitics where this concept was associated with the totalitarianisms of the twentieth century (Sanguin 1975). However, it is worth noting that, for all the 1970s, Lacoste did not explicitly define his work as geopolitics. As Paul Claval noted, 'the first issues of Hérodote in the mid-1970s were not devoted to

F.Ferretti, 2019 “A coffin for Malthusianism: Josué de Castro's subaltern geopolitics”, Geopolitics early view: https://www.tandfonline.com/doi/full/10.1080/14650045.2019.1583213 
geopolitics. The term was incorporated into the journal's sub-title only in 1983 (Revue de géographie et de géopolitique)' (Claval 2000, 245). In his famous book, Lacoste defined geopolitics as something 'which is being done, though the definition is not tasteful' (Lacoste 1976, 9), implying that geopolitics was still a prerogative of the power in place. In the first issue of Hérodote, the only author who discussed explicitly the term geopolitics, albeit without providing any operational definition, was Michel Foucault, famously interviewed by Lacoste (Foucault 1976).

According to Claval, the explicit adoption of the label geopolitics by Hérodote was a result of the increasing popularity of this term, which 'was frequently used in journals and the media' (Claval 2000, 248). While Ó Tuathail considers some of Lacoste's works like his research on the dike bombing strategy deployed by the US Army during the Vietnam War as a 'brilliant example of counter-geopolitics' (Ó Tuathail 1996, 128), the author of Critical Geopolitics finally argues that Lacoste's works fail 'to specify in a detailed way how geographical knowledge functions strategically as a form of power/knowledge' (Ó Tuathail 1996, 133). If I quote this statement, it is not to undermine the importance of Herodote, which is widely acknowledged, but to stress how earlier de Castro's work stood in anticipating later uses of the word geopolitics in critical and radical terms, especially in France, which was doubtlessly his second country for both his biography and his scholarly circuits. Like Foucault, Lacoste was one of de Castro's colleagues in Vincennes, and it is similarly striking to notice that de Castro was rarely quoted in the first issues of Hérodote. When it happened, it was generally in relation to specific Brazilian issues rather than geopolitical concepts, like in the case of a Bernard Bret's paper on droughts in the Northeast (Bret 1982) or in texts of Brazilian authors, like a famous interview with Milton Santos (Ferretti and Viotto 2018).

While de Castro's mobilisation of the term geopolitics seems to have been poorly acknowledged in France, in the 1952 English translation of Geopolítica da fome this definition was even wittingly hidden, as both the English and the North-American edition were titled Geography of Hunger. This can also create some misunderstanding, because this title corresponds to the former de Castro's book, Geografia da fome on hunger in Brazil, which was never translated into English. The London Gollancz edition was prefaced by Scottish biologist

F.Ferretti, 2019 “A coffin for Malthusianism: Josué de Castro's subaltern geopolitics”, Geopolitics early view: https://www.tandfonline.com/doi/full/10.1080/14650045.2019.1583213 
John Boyd Orr (1880-1971), former chair of the FAO and Nobel Prize for Peace in 1949, who was accordingly one of the international functionaries unwilling to add fuel to the fire in the early years of the Cold War by resuming badly reputed words like geopolitics. Yet, Orr wrote enthusiastically on de Castro's book, saluting it as an intellectual instrument for 'saving our civilisation from perishing in a third world war' (Boyd Orr 1952, 5). Like Sorre, Orr especially highlighted de Castro's strong anti-Malthusian inspiration, noticing the effectiveness of his arguments in showing that 'there is no physical difficulty in doubling or redoubling the world food supply' (Boyd Orr 1952, 6). However, only in the 1977 edition of the Monthly Review Press was the corresponding title Geopolitics of Hunger re-established instead of the former one, defined 'ambiguous' (Berlan 1977, 20) in the foreword by Jean-Pierre Berlan. While there is no explicit explanation of the reasons which led the editors of the 1952 version to choose the definition of Geography, it is possible to hypothesize that the word geopolitics was still troublesome in the Anglo-American world, especially for the United Nations agencies which supported this editorial project.

In his 1952 preface to Géopolitique de la Faim (which did not appear in the English editions published in the same year), de Castro provided theoretical explanations for his notion of geopolitics, mainly based on the idea that engaged scholarship can help changing the world. After his works on hunger in Brazil, de Castro declared that he felt the need for a book 'being something more than a geography of hunger. It should be some geopolitics of hunger, connecting contemporary political and biological crises' (Castro 1952a, 20). Ironically, de Castro defined his project as more 'dangerous' (in the sense of its prickliness) than the former one, because in addition to the term hunger, it contained a word 'so compromised, devoid of its essential signification, contaminated and execrated' (Castro 1952a, 21) like geopolitics. Thus, the author explicitly alluded to a possible different meaning for that term. For de Castro, 'albeit degraded by Nazi dialectics, the word geopolitics still maintains its scientific rank and should be rehabilitated in its true sense. Such rehabilitation is worthy of taking the risk to be exposed to hastily interpretations from the title's reading' (Castro 1952a, 21). Therefore, de Castro was well aware of the dangers which this terminological choice might have entailed for his reputation.

F.Ferretti, 2019 “A coffin for Malthusianism: Josué de Castro's subaltern geopolitics”, Geopolitics early view: https://www.tandfonline.com/doi/full/10.1080/14650045.2019.1583213 
Nevertheless, the Brazilian scholar exposed the principles of what today could be considered as subaltern or non-statist geopolitics, which did not deal with statecraft, but first performed social denunciations. 'The true sense of the term geopolitics is that of a scientific discipline which tries to establish relations between geographical factors and political phenomena, to show that political directions could not be understood independently by geographical frameworks, i.e. separated from the realities and contingencies of natural and cultural milieus. Clearly, geopolitics intended this way has nothing to do with the pseudo-scientific German Geopolitik by Karl Haushofer, which only was a nebulous mixture of contradictory principles whose only goal was to justify the expansionist ambitions of the Third Reich. ... What I call geopolitics is not the art of political action in the conflicts among states, or a magic formula to predict history, as [Oswald] Spengler pretended. It is only a method for the interpretation of political dynamics in their spatial realities, with their roots in the environing soil. Few phenomena have been more influential on the peoples' political behaviours than alimentation and the tragic need for food. Here you are the living and coarse reality of geopolitics of hunger' (Castro 1952a, 21). These subaltern geopolitics were aimed at mobilising public opinion and encouraging social protest in the countries of what was then called the Third World. For that, the first adversary to challenge was Malthusianism.

\section{Countering Malthus: geopolitics of hunger and food insecurity}

In the last 10 years or so there has been an increasing interest in geographies of food (Cook et al. 2010). More specifically, recent work by David Nally has contributed greatly to highlighting "the hypocrisy of the "hungercrats" who publicly warn[ed] the poor of the coming austerity, instructing them to "tighten their belts" [while] reproducing ideas of Western philanthropy and humanitarianism' (Nally 2016, 559-60). The object of Nally's criticism is the rhetoric on food security, which he considers as the contemporary expression of neo-colonial stereotypes on the alleged 'civilising mission' of Northern countries (Nally 2015). For Nally, this rhetoric is especially deployed by technocrats and economic actors interested in establishing consensus 'on a series of mythologies about food insecurity [which] lend legitimacy to domination' (Nally 2016, 561). Nally identifies four of these mythologies: the first, techno-optimism, argues that 'there is a cure-all, engineering solution to virtually every social problem we face' (Nally, 2016, 563). The second is the neo-positivist idea that traditional peasantry and smallholders are

F.Ferretti, 2019 “A coffin for Malthusianism: Josué de Castro's subaltern geopolitics”, Geopolitics early view: https://www.tandfonline.com/doi/full/10.1080/14650045.2019.1583213 
inefficient, and that 'development' should come from Northern recipes assuming that: 'They are passive; we were active; they lack, we impart' (Nally 2016, 569). The third myth is scarcity, leading to the coming back of Malthusianism, an idea which Amartya Sen, quoted by Nally, defines as 'a black cat in a dark room that is not there' (Nally 2016, 577). The fourth myth is the idea that fully liberalised markets are essential for rural development and food security, refreshing old notions of the 'White man burden to fill the mouth of famine' (Nally 2016, 582). De Castro's geopolitics of hunger provided useful insights for this debate by advocating for agrarian reform, supporting peasants' unions in Brazil and challenging Malthusianism, neocolonialism and social inequalities.

Contemporary scholarship also addresses historical experiences of what Mike Davis defined 'Victorian Holocausts' (Davis 2001), associated with imperial appetites for getting rid of what Nally later called 'human encumbrances' (Nally 2011). For Nally, and for Gerry Kearns, the example of the nineteenth century Irish Great Famine showed how little natural and how much socially engineered historical famines were, being their causes more 'of geopolitics than of local environmental failure' (Nally and Kearns 2011). In his books Geografia da fome (1946), analysing hunger in Brazil, and Geopolítica da fome (1952), analysing hunger worldwide, de Castro anticipated much of these arguments. It is astonishing that one of the inspirers of present-day readings of food security as a biopolitical strategy, Michel Foucault, likewise overlooked de Castro's work, though the French philosopher was a de Castro's colleague at the Vincennes University from 1969 to 1973 (Bué 2009). As I explain below, de Castro was often ignored also because of his non-conformism, which rendered him a thorny intellectual for both conservatives and 'progressives' in the polarised world of the Cold War.

Writing and disseminating books like Geopolitics of Hunger was one of the first ways that de Castro envisaged to sensitise international public opinion and social movements on his geopolitical agenda. In his work, the Brazilian geographer advocated for engaged science and made his main argument against the idea that hunger was a "natural and irremediable phenomenon' (Castro 1952a, 33), showing awareness of both Marxist and anarchist traditions to counter Malthusianism, by arguing that: 'Fourier, Proudhon, Engels, and Kautsky likewise denounce the artificial nature of Malthusian theory' (Castro 1952a, 36). To counter Malthusian

F.Ferretti, 2019 “A coffin for Malthusianism: Josué de Castro's subaltern geopolitics”, Geopolitics early view: https://www.tandfonline.com/doi/full/10.1080/14650045.2019.1583213 
recipes considering poverty as a natural phenomenon, de Castro inverted commonplace understandings of hunger's causes and effects by arguing that: 'It is not overpopulation which creates famines, but famine which creates overpopulation' (Castro 1952a, 47). On this point, de Castro drew upon empirical evidence suggesting that birth rates increase as a consequence of misery rather than being its cause, as ironically exposed in a North-eastern popular proverb which he recounted to Jean Ziegler: 'The table of a poor man is meagre, but the bed of poverty is fecund' (Ziegler 2013, 74). More recent works in historical demography suggest that de Castro was substantially right, as authors like Massimo Livi Bacci consider that the availability of food was a relatively secondary element in the growth of big populations, and that the only effective way to reduce natality was the progressive spread of urban ways of life in which having many children became rather a cost than a resource (Livi Bacci 2017).

For de Castro, a key goal was studying not only starvation, but also what he called a 'gamut of hungers', namely 'qualitative hungers' constituted by specific deficiencies in one or more vitamins. De Castro considered all these as the result of social and colonial relations rather than as 'natural poverty' explained by droughts or other environmental reasons (Buckley 2017). In his worldwide survey of hunger, de Castro provided examples of African tribes in whose traditional ways of life no alimentary deficiencies were recorded, while 'as soon as they go work in the factories and take up a diet under European influence, typical deficiency diseases ... begin to destroy large numbers of them' (Castro 1952b, 37). Another example was the rising of specific vitamin B hunger in Amazonia during the rubber boom, due to the generalised consumption of 'canned European food' (Castro 1952b, 54). Addressing European endeavours in Polynesia, de Castro implicitly recalled Denis Diderot's anti-colonialism (Muthu, 2003), translating this critique in alimentary terms by observing that, in name of morality, missionaries 'covered [the indigenous'] bodies with heavy clothing, cutting off their healthful supply of vitamin D' (Castro 1952b, 61). Historically, de Castro adopted a global anti-imperialist perspective, arguing for instance that in nineteenth-century China, a country which was never formally colonised, political disorganisation was fostered 'by the imperialists' (Castro 1952b, 145). About the Irish case, de Castro anticipated some arguments of the literature referred to above, by arguing that the cause of the Great Famine was not nature, but the 'agrarian problem' (Castro 1952b, 197), that is British colonialism. Analysing the situation of his day, de Castro

F.Ferretti, 2019 “A coffin for Malthusianism: Josué de Castro's subaltern geopolitics”, Geopolitics early view: https://www.tandfonline.com/doi/full/10.1080/14650045.2019.1583213 
raised anticolonial arguments, deeming 'injudicious colonialism' (Castro 1952b, 95) the monoculture imposed by American corporations in Southern and Central America to the detriment of food supply for local consumption. This provides arguments for current critiques of 'food security', in particular to counter the commonplace assumptions pretending the inefficiency of small peasantry, while, for de Castro, production for self-consumption was one of the key solutions against global hunger. More generally, de Castro's geopolitics appear to be a definitively anti-colonial and anti-racist field of study, deserving the definition of 'subaltern' set out above.

The Brazilian geographer further confirmed his anti-racist positions by defining deficient nutrition as the primary cause of physical problems often observed in tropical peoples, which were mistakenly considered 'racial characteristics' (Castro 1952b, 41) by most of Western authors. For de Castro, geopolitics of hunger definitively confirmed 'the anthropologists' findings that there are no biologically superior or inferior races' (Castro 1952b, 82). Accordingly, de Castro argued that also the big events of European history derived significant motivations from hunger, like in the case of the French Revolution, on which he mentioned the idea of historian Jules Michelet on the need for a History of Hunger, unrealised at that time. According to de Castro, after the 1929 world financial crisis, hunger was one of the key reasons for the emergence and popular support of Fascism and Nazism in Europe and Japan. These statements confirm how anti-racism and multiculturalism were intrinsic characteristics of de Castro's subaltern geopolitics.

Finally, de Castro's claims for a 'geography of abundance' can still inspire current antiMalthusian arguments in development studies (Peet and Hartwick 2015). Recalling Reclus's claims that the production of food could have been increased to the point of satisfying all the global needs for food supply, as the problem was not the scarcity of resources but their uneven distribution (Ferretti 2011), de Castro confirmed the militant nature of his geopolitics by statements like: 'The Malthusians go on setting up their sinister scarcecrows. It is nothing to us, since we have no reason to fear them' (Castro 1952b, 250). Therefore, geopolitics of hunger would have meant making 'the transition from a colonial economy to a co-operative world economy based on mutual interests' (Castro 1952b, 257), whose result, the Geography of

F.Ferretti, 2019 “A coffin for Malthusianism: Josué de Castro's subaltern geopolitics”, Geopolitics 
Abundance, 'will be matched by new social structures, which will guarantee the attainment of a new stage in the universal search for happiness and social well-being' (Castro 1952b, 258). For de Castro, food security should not be a pretext for corporate or imperial interests, but a concrete task for social movements and engaged intellectuals. In the next section, I explain how de Castro tried to use the only weapons available to him after the revocation of his civil rights in Brazil and his exile in Paris in 1964, that is his scholarly production and his multilingual networks, as instruments for radical geopolitical activism, also thanks to his early French connections discussed above.

\section{Activism in Brazil and in exile}

\subsection{Activism with North-eastern subalterns}

One of the most impressive of de Castro's works, The Cycle of the Crab, which was first published as a short story in 1935 and later as a longer novel entitled Men and Crabs (1967), was relatedly inspired by the first-hand experiences of young de Castro wandering through the mocambos surrounding Recife, settled by poor communities of indigenous and Afro-Brazilian descent potentially representing Dipesh Chakrabarty's definition of the subaltern as a 'nonindustrial revolutionary subject' (Clayton 2011, 248). The author described this ecosystem between land and rivers as something extending beyond social and economic conventions of territory and private property. 'In the mangroves, land does not belong to anybody. It belongs to the tide. ... There, caboclo Zé Luis built his mocambo' (Castro 2007, 105). As de Castro claimed in the preface to Men and Crabs, this experience with poverty and suffering had formed the basis of his training and remained a central point in his subaltern geopolitics. 'It was not at the Sorbonne or at any other savant university that I learned of the phenomenon of hunger. It appears spontaneously to me in the mangroves of Capibaribe, in the miserable neighbourhoods of Recife ... This was my Sorbonne: the mud of the Recife mangroves, simmering with crabs and populated with human beings made of crab flesh, thinking and feeling like crabs. Amphibious beings, dwellers of land and water... siblings of the crabs' (Castro 2007, 142). In this mature work, poetic images merge with a consciousness of the origins of this society, where mangroves served as a metaphor for slavery and exploitation. 'So they were all sunk in the mangrove, tied by the suckers with which the insatiable mangroves

F.Ferretti, 2019 “A coffin for Malthusianism: Josué de Castro's subaltern geopolitics”, Geopolitics early view: https://www.tandfonline.com/doi/full/10.1080/14650045.2019.1583213 
absorbed all the juices of their slaves' flesh and souls... In this region, everything belongs to the conqueror and dominating mangrove: man and land' (Castro 2007, 143). In this society, humans and non-humans interact not as a result of naturalistic determinism, but as an outcome of the specific social conditions of Brazil and Latin America, which de Castro considered to be still characterised by feudal relations introduced by early colonialists. 'The first society I was acquainted with was that of the crabs. Then, it was that of the mangroves' human dwellers and of siblings of the crabs. ... In my book, I tell the story of this amphibian society, which is amphibian itself, as it vegetates along the margins of two economic structures that history never merged until today in the Northeast: the agrarian feudal structure and the capitalist one' (Castro 2007, 145).

For de Castro, solutions to these problems were first associated with his experience as a supporter of agrarian reform and peasants' leagues in the Northeast. According to the author of a substantial Brazilian dissertation on the geographies of hunger, Cleder Fontana, de Castro was 'a close friend of Francisco Julião' (Fontana 2014, 111). The advocate and supporter of the first leagues in the Engenho Galilea in the Pernambucan Sertão, Julião was likewise banished by the military dictatorship after 1964. De Castro supported the North-eastern peasants' leagues through his activity as a member of the federal parliament (Santos Silva 2016) and chaired their first congress in Recife in 1955 (Fontana 2014, 182). Indeed, it is not coincidental that one of de Castro's key works, Sete palmos de terra e um caixão, translated into English as Death in the Northeast [literally, the title would read Seven feet of land and a coffin], highlights anecdotes by the struggles inaugurated at the Engenho Galilea. For instance, these leagues' earliest claim 'was not primarily, as one would think, the improvement of living conditions ... Actually, the League's original purpose was to advance the interests of the dead, victims of hunger, misery ... to secure for the peasants the right to six feet of earth in which they might rest ... and the privilege of being buried in wooden coffins of their own' (Castro 1969, 7-8). Foreseeing the astonishment of his Western readers, de Castro explained the cultural and symbolic significance of this claim with a very simple and materialistic argument: in a region where most of the population suffers desperate conditions of life, 'it is death, not life, that really counts' (Castro 1969, 8). In a situation where 'the legacy of slavery remains in force ... the folk singers at fairs have always extolled the indomitable courage of people's

F.Ferretti, 2019 “A coffin for Malthusianism: Josué de Castro's subaltern geopolitics”, Geopolitics early view: https://www.tandfonline.com/doi/full/10.1080/14650045.2019.1583213 
leaders who have given their lives for justice' (Castro, 1969, 9), for instance by defending the seventeenth-century quilombo [Black republic] of Palmares led by legendary slave Zumbi. According to de Castro, no peasant feared death, which was considered a liberation merging elements of both Christian and traditional African religions. As normal burying ceremonies occurred with borrowed coffins that served only before the corpse's deposition in the graveyard and were then reused for other poor people, 'this travesty of ceremony was the supreme humiliation [and] the first League was created to escape this shaming' (Castro 1969, 12). In his book, the geographer derided what he referred to as the two discoveries of the Northeast (by the Portuguese and then by the North-Americans), which he deemed 'an error of navigation in 1500 and an error of interpretation in 1960' (Castro 1969, 3), that is the suspicion that social insurgency in this region was part of a plot organised by the Soviet Union. For de Castro, the endogenous roots for insurgency in the Northeast of Brazil were due to genuine 'geographies of despair', ${ }^{20}$ and a far cry from Cold War conspiracies.

Finally, de Castro denied any naturalization of poverty and hunger. While his attention for environments and multiple agencies can be considered as a marker of his subaltern geopolitics involving humans and non-humans, his performances in writing social novels like The Cycle of the Crab can be considered as part of a strategy for popularising social critiques and fostering subaltern agency, that is geopolitics from below. In the Northeast, and more broadly in Brazil, this became part of popular culture: Pernambucan singer Chico Science (1966-1997) took explicitly inspiration from de Castro's works on crabs, mangroves and mocambos in leading the Manguebeat political-artistic movement that claimed for social justice and recovered AfroBrazilian roots of the region in the 1990s. In the documentary Josué de Castro cidadão do mundo, containing interviews with intellectuals acquainted with de Castro such as Santos and de Andrade, Chico Science complained about de Castro's forgetting in Brazilian schools, calling for rediscovering his life and work: 'Guys, you must know who Josué de Castro was!' (Tendler 1994).

\subsection{Activism through exile}

${ }^{20}$ CEHIBRA, 243, Géographie du Desespoir.

F.Ferretti, 2019 “A coffin for Malthusianism: Josué de Castro's subaltern geopolitics”, Geopolitics early view: https://www.tandfonline.com/doi/full/10.1080/14650045.2019.1583213 
After his election to the Chair of Geography at the Rio de Janeiro University of Brazil in 1939, de Castro networked intensely in Brazil and Latin America to sensitize scholars and politicians to the problems of hunger. The setting up of the Brazilian Institute of Nutrition was a key outcome of these efforts. ${ }^{21}$ From 1955 to 1963, de Castro was a member of the Federal Parliament in Brazil and had important international appointments as Chair of the FAO from 1952 to 1956, Brazilian ambassador at the UNESCO and member of the WHO scientific committee. Up to 1964, he represented Brazil in the United Nation offices in Geneva. ${ }^{22}$ Frequently in relation with countries of the Eastern Bloc where he was invited on several occasions, de Castro was also active in the World Peace Council and supported international initiatives for disarmament. In 1957, in Paris, de Castro founded the ASCOFAM (Association Mondiale de Lutte Contre la Faim), counting on famous testimonials like Boyd Orr and Abbé Pierre. While these activities reveal de Castro's early willingness to exert pressure on political decisions, which characterise today progressive and alter geopolitics (Kearns 2008; Koopman 2011), his scholarly international networking proved fundamental to pursuing informally his diplomatic activities against hunger without the support of his government after the cessation of his political rights and his subsequent exile in France from 1964.

The first step of this work was the foundation in Paris of the CID by proposing 'a new doctrine of development' ${ }^{23}$ and the involvement of both institutional and non-institutional actors. 'Our centre is very international and open to everybody. It includes not only capitalist countries but also socialist ones such as Poland ... non-governmental institutions and private groups. It is time to stop employing policies of aid that are too often policies of charity for neo-colonialist propaganda' ${ }^{24}$ For de Castro, the CID had to work as a 'group of pressure ... to change the politics of international cooperation... based on principles different from those which have been hitherto implemented through so-called international aid'. ${ }^{25}$ At the 'margins' of geopolitics, de Castro tried to continue putting pressure on governments through conferences, publications and international networking.

\footnotetext{
${ }^{21}$ CEHIBRA, 164, Biografia resumida.

${ }^{22}$ CEHIBRA, 393, Biografia

${ }^{23}$ CEHIBRA, 393, Biografia.

${ }^{24}$ CEHIBRA, 150, Professeur Josué de Castro.

${ }^{25}$ CEHIBRA, 393, Biografia.
}

F.Ferretti, 2019 “A coffin for Malthusianism: Josué de Castro's subaltern geopolitics”, Geopolitics early view: https://www.tandfonline.com/doi/full/10.1080/14650045.2019.1583213 
The second step were the teaching appointments which de Castro gained in Paris thanks to his popularity and reputation in French scholarly and progressive milieus, the first of which was at the IEDES (Institut d'étude du développement économique et social), where also Milton Santos worked (Ferretti 2018). De Castro's subsequent appointment at the University of Paris VIII in Vincennes from 1968 to 1973 stood in continuity with his political and diplomatic work. This new university was then a 'refuge' for leftist intellectuals after 1968 and a place for experimenting new pedagogic methods. Of de Castro's colleagues there, one can mention Lacoste, Foucault, Gilles Deleuze, François Lyotard and other famous 'French Theorists'. Though few documents remain on de Castro's relations with them, his syllabi and Vincennes working documents stored in Recife are overwhelmingly focused on what he called 'The Threat of Civilisation' ${ }^{26}$ (upsetting the classical formula of 'threats to civilisation' he used formerly). A key point of de Castro's works in Vincennes was his attempt to define the concept of human ecology and to apply it to the field of development to resolve the contradiction between economic growth and the devastation of social and ecological environments. According to de Castro, the concern of destroying the planet was inaugurated by Cold War anxieties over the proliferation of atomic weapons. He then envisaged a close link between anti-hunger and antiwar struggles as witnessed by his correspondence with progressive intellectuals committed to the same aims like Bertrand Russell. ${ }^{27}$ This association between pacifism and anti-hunger policies seems to have only characterised unorthodox scholars at that moment, highlighting de Castro's non-conformism and his attempts to embrace concerns from both 'Northern' and 'Southern' colleagues.

Very sensitive to Albert Camus's concerns for 'changing the world to avoid its selfdestruction, $^{28}$, de Castro came to question the values of technologic and scientific progress, arguing that an assessment of science cannot disregard its social uses: the limits and contradictions of scientific progress, unable to feed everybody, were showing 'the powerlessness of the big powers ${ }^{29}$. In Vincennes, the Brazilian geographer led a research

\footnotetext{
${ }^{26}$ CEHIBRA, 303.

27 CEHIBRA, 115, de Castro to Russell, 25 May 1964.

${ }^{28}$ CEHIBRA, 150.

${ }^{29}$ CEHIBRA, 150.
}

F.Ferretti, 2019 “A coffin for Malthusianism: Josué de Castro's subaltern geopolitics”, Geopolitics early view: https://www.tandfonline.com/doi/full/10.1080/14650045.2019.1583213 
cluster on the 'environment and pollution' especially focussing on those 'developing' countries where 'the imported technological progress seriously threatens regional ecological balance and inhabitants' conditions of life'. The first aim of the research group was 'a study of the Amazonian Basin, the largest natural reserve at humankind's disposal that maintains breathable air on our planet' ${ }^{30}$ In writing to a Le Monde journalist to advertise his initiative, de Castro clarified that the problem involved was 'the protection of the human environment from the threats of development and civilisation'. ${ }^{31}$ De Castro's ecological views were never disjoined from a humanistic and cultural perspective sensitive to the interactions of diverse human groups with diverse environments. These elements of non-conformity with dominant theories of modernization in this period accordingly contributed to his fall into obscurity: being at the same time environmentalist, anti-Malthusian, concerned with food supply and wary of technocracy was not a way to match mainstream development debates of that decades.

In Vincennes, modules delivered by de Castro included those entitled 'Initiation to Human Ecology', 'Agrarian Structures and Problems of the Bidonvilles in Latin America', 'Third World Human Ecology' and 'Central America'. Though affiliated with the Geographical Institute, de Castro continued to state a need for interdisciplinary approaches to hunger viewed as 'bio-social phenomena' ${ }^{32}$ requiring the application of different disciplines to grasp the ecological nexuses to be understood to derive potential solutions. The neglect of these nexuses was again attributed to imperial legacies in that inadequate economic structures such as colonial exploitation impeded the rational utilisation of soils worldwide, going against the interests of Indigenous peoples'. ${ }^{33}$ In his syllabus for 'Introduction to Human Ecology', de Castro argued that 'the new geographical science cannot overlook environmental analyses or give up the application of ecological methods [because such studies are] indispensable for geographers, historians and sociologists for understanding complex problems related to correlations between human quality of life and human habitats' ${ }^{34}$

\footnotetext{
${ }^{30}$ CEHIBRA, 303.

${ }^{31}$ CEHIBRA, 303, de Castro to Fontaine, 2 March 1973.

${ }^{32}$ CEHIBRA, 183, Vincennes.

${ }^{33}$ CEHIBRA, 183, Vincennes.

${ }^{34}$ CEHIBRA, 183, Vincennes.
}

F.Ferretti, 2019 “A coffin for Malthusianism: Josué de Castro's subaltern geopolitics”, Geopolitics early view: https://www.tandfonline.com/doi/full/10.1080/14650045.2019.1583213 
A module entitled 'Third World Human Ecology', which de Castro delivered with Alain Bué and Magda Zanoni, addressed different ecological relations existing in 'countries viewed as underdeveloped' and called for the questioning of hasty terms such as the 'Third World ... a rather vague geographical entity'. Furthermore, he argued that 'programs against underdevelopment will not succeed if they do not consider an environment whose mechanisms they want to change'. This environment was not intended as a 'natural' one, but as a complex ensemble wherein "the variable "culture" should be used as a precious analytical tool to define ecosystems and should be considered the result of interactions between bio-social dynamics and the complex of the physical, biological, economic and technological environment' ${ }^{35}$ The syllabus of his module on bidonvilles likewise states a need to consider 'ecologic frameworks to fight against the abnormal and anti-economic distribution of resources in Latin America' ${ }^{36}$ A module entitled 'Introduction to the problems of under-development' was scheduled for 1973-74 and accordingly not delivered by Josué, who died in September 1973. The syllabus proposed a new notion opposed to 'the classical concept of underdevelopment as the expression of static or backward economies', defining it instead as the 'expression of global economic disintegration'. ${ }^{37}$ Thus, underdevelopment became synonymous with poverty everywhere, consistent with de Castro's commitment to addressing cases of poverty in the 'First World' as witnessed for instance from his correspondence with Italian activist Danilo Dolci, who had been engaged in projects for full employment in Sicily. ${ }^{38}$ This matches contemporary definitions of the 'Global South' as a complex geopolitical entity that can be found 'everywhere, but always somewhere' (Sparke 2007, 124). It is possible to conclude by arguing that de Castro's scholarly activities in France were an attempt to extend his political and diplomatic engagement and constituted his personal attempt to perform his idea of critical geopolitics from below through socially committed scholarship and international networking.

\section{Conclusion}

De Castro's intellectual legacy gained a new wave of public interest in Brazil thanks to the outcomes of the peasants' movement MST (Movimento dos Trabalhadores Rurais Sem Terra),

\footnotetext{
${ }^{35}$ CEHIBRA, 183, Vincennes.

${ }^{36}$ CEHIBRA, 300.

${ }^{37}$ CEHIBRA, 183, Vincennes.

${ }^{38}$ CEHIBRA, Folders 559, 561, 568, 569.
}

F.Ferretti, 2019 “A coffin for Malthusianism: Josué de Castro's subaltern geopolitics", Geopolitics early view: https://www.tandfonline.com/doi/full/10.1080/14650045.2019.1583213 
while his ideas on the need for a reappreciation of small peasantry and local ways of life for basic food supply still inspire global counter-networks of land workers like La Via Campesina (Peet and Hartwick 2015; Stahler-Sholk, Vanden and Becker 2014). The reasons for de Castro's neglect in international politics during his life and in global scholarship today are complex and can be the object of further work. As a first contribution to these questionings, I would argue that de Castro was first side-lined because his positions were unorthodox for both conservatives and progressives. In the context of the Cold War, being a radical social critic without embracing Marxism or any other well defined political ideology meant substantial unpopularity among the tenants of both the Western and the Eastern bloc, despite the number of collaborations which de Castro gained thanks to his political, diplomatic and scholarly work. Eventually, his interest in the social experiments for food production performed by some socialist countries contributed to foster suspicions of 'communism', which may have alienated him from several North-American intellectuals.

Critically, de Castro's works anticipated many of the debates preoccupying scholars in the field of geopolitics. This also occurred thanks to his position at the frontier of diverse cultures, well representing what Walter Mignolo calls 'border thinking' (Mignolo 2012). De Castro's multilingualism, multiculturalism and practiced internationalism, first as a diplomat and later as an exile, accordingly enabled him to develop an open-mindedness needed to go beyond common assertions of his time, like for instance the damnation of the term 'geopolitics'. Not only did de Castro pioneer the use of the word 'geopolitics' in critical terms, his works and networks contribute to nourish debates in this field of studies.

First, de Castro was the supporter of a geopolitics beyond the state: as Ziegler noticed, 'he broke the law out of necessity' (Ziegler 2013, 73) and pursued informal diplomacy through the CID and his scholarly networks, to extend his political agendas during his exile. Today, it is possible to hypothesise that his contribution continues to be prickly for mainstream geopolitical discourses, which critics consider to be still partially trapped in statist and territorialist readings (Agnew 2010). Second, de Castro's marginal position can extend to-day concepts of liminality, a notion admittedly close to that of subalternity, allowing to apply it to engaged scholars. This responds scholars' calls to look at the margins of geopolitics and to 'troubl[e] the stasis of

F.Ferretti, 2019 “A coffin for Malthusianism: Josué de Castro's subaltern geopolitics”, Geopolitics 
political subjectivity [raising] the question of who is, and who should be, a legitimate actor in international relations' (McConnell 2016, 150). Third, de Castro's works provide insights in progressive and alter-geopolitics by insisting on the notion of cooperative participation to address global issues, one which is likewise discussed by literature in these fields (Kearns 2008; Koopman 2011). Fourth, de Castro's works put subaltern histories in the broader field of geopolitics, anticipating current rediscoveries of non-European traditions of resistance by Afro-Brazilian or 'mixed' communities. He considered these cultural specificities as being central to understanding and resolving concrete problems of hunger and poverty. This echoes his early questioning of neo-colonial views of development as mere economic growth and imitation of 'Northern' models, contributing to contemporary notions on the 'geopolitics of knowledge' and 'colonial difference' (Mignolo and Escobar 2010). Fifth, de Castro's writings like Death in the Northeast and the Cycle of the Crab expressed an attention to the subaltern's concrete feelings and bodily sufferings, one which clearly challenges the traditional disembodiment of 'scientific' works later criticised by feminist geopolitics (Dowler and Sharp 2011).

However, these works should not be exempted from scrutiny. For instance, de Castro's explicit definition of geopolitics looks very loose (and sometimes naïve), and it is by putting together elements from the whole of his works and his trajectory that one can make fully sense of his geopolitical contribution, as I did in this paper. His trajectory was not a success story, but that of a painful failure. A possible reason for this is that de Castro never resolved the contradiction on whether anti-hunger action should be pursued from above (through the state and international agency apparatus) or from below (siding with grassroots movements). Moreover, he never really chose explicitly his political field, partially mirroring the political ambiguities of twentieth century international organisations highlighted by recent scholarship on the geographies of internationalism (Hodder, Legg and Heffernan 2015). De Castro's dialogue with both radicals and conservatives was a generous but rather utopian effort to get international institutions on the side of the poor, what effectively did not happen, as shown by the literature referenced here.

F.Ferretti, 2019 “A coffin for Malthusianism: Josué de Castro's subaltern geopolitics”, Geopolitics early view: https://www.tandfonline.com/doi/full/10.1080/14650045.2019.1583213 
Yet, it is also for these ambiguities that de Castro's geopolitics, remaining unfinished business, can still be a possible source of inspiration for current scholars in geopolitics and development studies. All these arguments talk to present-day discussions on 'food security' by challenging new forms of Malthusianism and by calling attention on the importance of local and cultural peculiarities, subaltern agency and bottom-up approaches to address issues of food supply and development. Finally, de Castro's often overlooked international networking not only provides an example of a non-institutional way to perform geopolitical discourses. It also confirms the need to rediscover voices from the South, alternative geographical traditions and their impact in shaping early critical international scholarship, which can still serve ongoing discussions on critical, radical and subaltern geopolitics.

\section{REFERENCES}

Agnew, J. 2010. Still trapped in territory? Geopolitics 15 (November):779-784.

Andrade, M.C.d. 2003. Josué de Castro e o Brasil. São Paulo: Editora Fundação Perseu Abramo.

Andrade, M.C.d. 2007. A Geografia no contexto das ciências sociais em Pernambuco. RBCS 22(65):9-15.

Berlan, J.P. 1974. Introduction. In Castro, J.d. Geography of Hunger. New York and London: Monthly Review Press, 9-48.

Borzacchiello da Silva, J. 2016. French-Brazilian Geography: the Influence of French Geography in Brazil. Berlin: Springer.

Boyd Orr, J. 1952. Foreword. In Castro, J.d. Geography of Hunger. London: Gollancz, 5-7.

Bret, B. 1982. Nordeste du Brésil: dominants et dominés face à la sècheresse. Hérodote 24:123135.

Buckley, E. 2017. Technocrats and the Politics of Development and Drought in TwentiethCentury Brazil. Chapel Hill: The University of Northern Carolina Press.

Bué, A. 2009. Josué de Castro, un visionnaire brésilien à Vincennes. In Vincennes, une aventure de la pensée critique, ed. J.H. Djian. Paris: Flammarion:126-129.

Carter, E., 2018. Population control, public health, and development in mid twentieth century Latin America. Journal of Historical Geography, early view https://www.sciencedirect.com/science/article/pii/S0305748817302128

F.Ferretti, 2019 “A coffin for Malthusianism: Josué de Castro's subaltern geopolitics”, Geopolitics early view: https://www.tandfonline.com/doi/full/10.1080/14650045.2019.1583213 
Castro, J.d. 1937. A alimentação brasileira à luz da geografia humana. Pôrto Alegre: Livraria do Globo.

Castro, J.d. 1946. A Geografia da Fome. Rio de Janeiro: O Cruzeiro.

Castro, J.d. 1951. Geopolítica da fome. Rio de Janeiro: Editora Casa do estudante do Brasil.

Castro, J.d. 1952a. Géopolitique de la faim. Paris: Les éditions ouvrières.

Castro, J.d. 1952b. Geography of Hunger. London: Gollancz.

Castro, J.d. 1965. Obras completas. Ensaios de biologia social. São Paulo: Editôra Brasiliense. Castro, J.d. 1969. Death in the Northeast. New York: Random House.

Castro, J.d. 2007. Textos escolhidos de Josué de Castro. In Josué de Castro, vida e obra, eds.

B. Mançano-Fernandes and C.W. Porto-Gonçalves. São Paulo: Expressão Popular: 103-173.

Chappell, J. 2018. Beginning to End Hunger. Food and the Environment in Belo Horizonte, Brazil, and Beyond. Oakland: University of California Press.

Claval, P. 2000. Hérodote and the French Left. In Geopolitical Traditions, eds. K. Dodds and D. Atkinson. London: Routledge:239-267.

Clayton, D. 2011. Subaltern space. In The SAGE Handbook of Geographical Knowledge eds. J. Agnew and D. Livingstone. London: SAGE:246-261.

Cook, I. et al. 2010. Geographies of food: 'Afters'. Progress in Human Geography 35(1):104120.

Dalby, S. 1991. Critical geopolitics: discourse, difference and dissent. Environment and Planning D - Society and Space 9(3):261-283.

Davis, M. 2001. Late Victorian Holocausts: El Niño Famines and the Making of the Third World. London:Verso.

Dodds, K. and D Atkinson. eds. 2000. Geopolitical Traditions. Routledge: London,

Dodds, K., Kuus M., and J. Sharp. eds. 2013. The Ashgate Research Companion to Critical geopolitics. Farnham, UK: Ashgate.

Dowler, L. and Sharp, J. 2001. A feminist geopolitics? Space and Polity 5:165-76.

Ferretti, F. 2011. Comment nourrir la planète: à propos d'une carte statistique. In La pensée du monde, eds. P. Rérat and E. Piguet. Neuchâtel: Presses Universitaires Suisses: 111-116.

Ferretti, F. 2014. Pierre Deffontaines et les missions universitaires françaises au Brésil: enjeux politiques et pédagogiques d'une société savante outremer (1934-1938). Cybergeo http://cybergeo.revues.org/

F.Ferretti, 2019 “A coffin for Malthusianism: Josué de Castro's subaltern geopolitics”, Geopolitics early view: https://www.tandfonline.com/doi/full/10.1080/14650045.2019.1583213 
Ferretti, F. 2018. Geographies of internationalism: radical development and critical geopolitics from the Northeast of Brazil. Political Geography 63: 10-19.

Ferretti, F. 2019. Decolonising the Northeast: Brazilian subalterns, non-European heritages and radical geography in Pernambuco. Annals of the American Association of Geographers, doi: $10.1080 / 24694452.2018 .1554423$

Ferretti, F. and B. Viotto Pedrosa. 2018. Inventing critical development: a Brazilian geographer and his Northern networks. Transactions of the Institute of the British Geographers, 43 (4):703717.

Flint, C., and V. Mamadouh. 2015. The multi-disciplinary reclamation of geopolitics: New opportunities and challenges. Geopolitics 20 (1):2.

Fontana C. 2014. Fome e questão ambiental: uma leitura a partir da obra de Josué de Castro (PhD Dissertation), Porto Alegre: UFRGS.

Foucault, M. 1976. Questions à Michel Foucault sur la géographie. Hérodote 1:76-85.

Hecht, S.B. 2013. The Scramble for the Amazon and the 'Lost Paradise' of Euclides da Cunha. Chicago: The University of Chicago press.

Heffernan, M. 2000. Balancing visions: Comments on Gearóid Ó Tuathail's critical geopolitics. Political Geography 19 (3):347-52.

Hodder, J., Legg, S. \& Heffernan, M. 2015. Introduction: historical geographies of internationalism, 1900-1950. Political Geography 49:1-6.

Kearns, G. 2008. Progressive geopolitics. Geography Compass 2 (5):1599-1620.

Koopman. S. 2011. Alter-geopolitics: Other securities are happening. Geoforum 42:274-284.

Kuus M. 2014. Geopolitics and Expertise Knowledge and Authority in European Diplomacy. Chichester: Wiley Blackwell.

Lacoste, Y. 1976. La géographie ça sert d'abord à faire la guerre. Paris: Maspero.

Livi-Bacci, M. 2017. A Concise History of World Population. Malden: Wiley-Blackwell.

Mançano-Fernandes, B. and C.W. Porto-Gonçalves. eds. 2007. Josué de Castro, vida e obra. São Paulo: Expressão Popular.

McConnell, F. 2016. Liminal geopolitics: the subjectivity and spatiality of diplomacy at the margins. Transactions of the Institute of British Geographers 42(1):139-152.

McConnell, F., Megoran, N and P. Williams. eds. 2014. Geographies of Peace. London/New York: Tauris.

F.Ferretti, 2019 “A coffin for Malthusianism: Josué de Castro's subaltern geopolitics”, Geopolitics early view: https://www.tandfonline.com/doi/full/10.1080/14650045.2019.1583213 
Megoran, N. 2010 Towards a geography of peace: pacific geopolitics and evangelical Christian Crusade apologies. Transactions of the Institute of British Geographers 35(2): 382-398.

Melgaço, L. 2017. Thinking outside the bubble of the Global North: introducing Milton Santos and 'the active role of geography'. Antipode 49(4): 946-951.

Melgaço L and C. Prouse. 2017. Milton Santos: Pioneer in Geography. London: Springer.

Mercille, J. 2013. Radical Geopolitics'. In The Ashgate Research Companion eds. K. Dodds, M. Kuus and J. Sharp. Farnham: Ashgate: 129-146.

Mignolo, W. and A. Escobar. eds. 2010. Globalization and the Decolonial Option. London: Routledge.

Mignolo, W. 2012. Local Histories/Global designs. Coloniality, Subaltern Knowledges, and Border Thinking. Princeton: Princeton University Press.

Muthu, S. 2003. Enlightenment Against Empire. Princeton: Princeton University Press.

Nally, D. 2011. Human encumbrances. Political violence and the Great Irish Famine. Notre Dame: University of Notre Dame Press.

Nally, D. 2015. Governing precarious lives: land grabs, geopolitics, and 'food security'. The Geographical Journal, 181 (4):340-349.

Nally, D. 2016. Against food security: on forms of care and fields of violence. Global Society 30:558-582.

Nally, D and G. Kearns. 2011. A Closer Look at Famine. The Chronicle of Higher Education (October https://www.chronicle.com/article/A-Closer-Look-atFamine/129408?key=SWt1KQVnNCQdbXhnZGwWMzsAYCA4OEt1 YSZLanIgblxUEA\% $\underline{3 \mathrm{D} \% 3 \mathrm{D}}$

Ó Tuathail, G. 1996. Critical geopolitics. Minneapolis: University of Minnesota Press. Pain, R. 2009. Globalized fear? Towards an emotional geopolitics. Progress in Human Geography 33(4):466-486.

Peet, R. and E. Hartwick. 2015. Theories of Development. London: The Guilford Press.

Power. M. 2003. Rethinking Development Geographies. London: Routledge.

Ramos de Angelo, M. 2010. Louis-Joseph Lebret e a SAGMACS na Formação do Grupo de Ação para o Planejamento Urbano no Brasil (PhD dissertation). São Carlos: USP.

Routledge, P. 1998. Anti-Geopolitics. In The Geopolitics Reader eds. G. Ó Tuathail, S. Dalby and P. Routledge. London and New York: Routledge: 236-248.

F.Ferretti, 2019 “A coffin for Malthusianism: Josué de Castro's subaltern geopolitics”, Geopolitics early view: https://www.tandfonline.com/doi/full/10.1080/14650045.2019.1583213 
Sachs, W. ed. 1992. The Development Dictionary. London: Zed Books.

Sampaio Machado, M. 2009. A Construçao da Geografia Universitaria no Rio de Janeiro. Rio de Janeiro: FAPERJ.

Sanguin A.L. 1975. L'évolution et le renouveau de la géographie politique. Annales de Géographie, 84 (463):275-296.

Santos Silva, M.F. 2016. Josué de Castro: um Autor do Legado Esquecido? (PhD Dissertation). Campinas: Unicamp.

Sharp J. 2000. Condensing the Cold War. Reader's Digest and American Identity. Minneapolis: University of Minnesota Press.

Sharp, J. 2011. Subaltern geopolitics: Introduction. Geoforum 42 (3):271-273.

Sidaway, J.D., Mamadouh, V. and M. Power. 2013. Reappraising geopolitical traditions. In

The Ashgate Research Companion to Critical Geopolitics, eds. K. Dodds, M. Kuus, and J. Sharp Farnham, UK: Ashgate: 165-87.

Sorre, M. 1952. Preface de l'édition francaise. In Castro J.d. Géopolitique de la faim. Paris: Les éditions ouvrières: 9-12.

Sparke, M. 2007. Everywhere but always somewhere: critical geographies of the Global South. The Global South 1-2:117-126.

Stahler-Sholk, R., Vanden, H. and M. Becker. eds. 2014. Rethinking Latin American Social Movements Radical Action from Below. London: Rowman \& Littlefield.

Teles de Carvalho, A.A. 2009. Josué de Castro e a inclusão da fome nos Estudos Geográficos do Brasil (PhD Dissertation). São Paulo: USP.

Tendler S. 1994. Josué de Castro Cidadão do Mundo. Documentary https://www.youtube.com/watch?v=fQrwW1sjHyI

Ziegler J. 2013. Betting on Hunger. Why the world still Goes Hungry. New York/London: The New Press.

F.Ferretti, 2019 “A coffin for Malthusianism: Josué de Castro's subaltern geopolitics”, Geopolitics early view: https://www.tandfonline.com/doi/full/10.1080/14650045.2019.1583213 